\title{
Cytokine production by human thymic epithelial cells: control by the immune recognition of the neurohypophysial self-antigen
}

\author{
H. Martens ${ }^{\text {a }}$, B. Malgrange ${ }^{\text {b }}$, F. Robert ${ }^{\text {a }}$, C. Charlet ${ }^{\text {a }}$, D. De Groote ${ }^{\text {a }}$, D. Heymann ${ }^{\text {c }}$, \\ A. Godard ${ }^{\text {c }}$, J.P. Soulillou ${ }^{c}$, G. Moonen ${ }^{\text {b }}$, V. Geenen ${ }^{\text {a,* }}$ \\ ${ }^{a}$ Institute of Pathology CHU-B23, Lab of Radio-Immunology and Neuroendocrine-Immunology, University of Liège, B-4000 Liège-Sart Tilman, Belgium \\ ${ }^{\mathrm{b}}$ Department of Human Physiology and Pathophysiology, University of Liège, 17, place Delcour, B-4020 Liège, Belgium \\ ' INSERM U437, Institut de Transplantation et de Recherche en Transplantation, CHU-Hôtel Dieu, Bld. J. Monnet, F-44035 Nantes Cedex 01, France
}

Received 8 February 1996; accepted 14 May 1996

\begin{abstract}
Oxytocin (OT) has been shown to be the dominant peptide of the neurohypophysial family expressed by thymic epithelial and nurse cells (TEC/TNC) in various species. Thymic OT is not secreted but, after translocation of a hybrid neurophysin/MHC class I protein, is integrated within the plasma membrane of TEC, thus allowing its presentation to pre-T cells. In order to further demonstrate that thymic OT behaves like a membrane antigen, we assessed the effect of mAbs to OT on cytokine productions by cultures enriched in human TEC. 75-85\% pure TEC cultures were prepared from human thymic fragments. Using immunofluorescence and confocal microscopy, ir-OT, ir-interleukin-1 $\beta$ (IL-1 $\beta$ ), ir-interleukin-6 (IL-6) and ir-leukemia inhibitory factor (LIF) could be detected in these TEC cultures. ir-OT was restricted to TEC, while some ir-IL- 6 and ir-LIF were also seen in occasional fibroblasts. In basal conditions, ir-IL- 6 and ir-LIF (but not ir-OT and ir-IL-1 $\beta$ ) were detected in the supernatants of human TEC cultures. MAbs to OT induced a marked increase of ir-IL- 6 and ir-LIF secretion in TEC cultures. No significant effect was observed using mAbs against vasopressin, mouse immunoglobulins, or control ascitic fluid controls. These data show that OT is fully processed and recognized by specific mAbs at the outer surface of TEC plasma membrane. They further support that thymic OT behaves as the self-antigen of the neurohypophysial family.
\end{abstract}

Keywords: Thymus; Neurohypophysial peptide family; Self-antigen; T-cell self-education

\section{Introduction}

The epithelial component of thymic stroma plays an important role in positive and negative selection of $\mathrm{T}$ lymphocytes, [1-7]. The thymic repertoire of neuroendocrine-related polypeptide precursors has been proposed to recapitulate at the molecular level the dual physiologic role played by the thymus in T-cell development [8-10]. With a special regard to the neurohypophysial peptide family, our group as well as others have shown that thymic epithelial and nurse cells (TEC/TNC) synthesize oxytocin (OT) and its precursor-associated protein, OT-neurophysin $[11,12]$. Thymic OT plays a dual role in T-cell selection. First, following its interaction with cognate receptors expressed on $T$ cells $[13,14]$, OT acts as a cryptocrine signal involved in an accessory pathway of T-cell positive selec-

\footnotetext{
${ }^{*}$ Corresponding author.
}

tion $[15,16]$. Second, OT has been suggested to be the prototype neurohypophysial self-antigen presented to immature $\mathrm{T}$ cells by the thymic major histocompatibility complex (MHC) system.

Although ir-OT concentrations in the human thymus are much higher than those of ir-vasopressin (VP), both neurohypophysial ( $p r o O T$ and proVP) genes are transcribed in the human and murine thymus $[17,18]$. Thymic OT is not secreted but translocated in TEC plasma membrane in association with a membranal $55-\mathrm{kDa}$ neurophysin/MHC class I hybrid protein [19]. A functional analogy was observed in the binding and transport of OT between neurophysin in the hypothalamo-neurohypophysial axis [20] and the neurophysin domain in the thymic microenvironment. Presenting OT in such a manner to pre-T cells is thought to lead to the central T-cell tolerance in neurohypophysial family members [21]. This model of T-cell education to the neurohypophysial self-antigen offers selective advantages such as avoiding MHC class I allelic 
restriction and presenting the overall conformational structure of the neurohypophysial peptide family.

TEC also express transcripts and proteins of various cytokines, such as interleukin 1 (IL-1) [22], interleukin 6 (IL-6) and leukemia inhibitory factor (LIF) [23] which were also found in the supernatants of TEC cultures. We previously showed ir-IL- $1 \beta$ to be colocated with ir-OT and its neurophysin in thymic sections, more specifically in TEC recognized with cytokeratin (CK) antibodies [24].

In the immune system, T-cell activation and cytokine production usually follow the recognition and binding of Abs to antigenic markers expressed on the surface of T-cell membranes. In an attempt to unravel the physiological significance of the colocalization of OT with other polypeptides in TEC, we investigated the effect of anti-OT monoclonal antibodies (mAbs) upon IL-1 $\beta$, IL-6 and LIF secretion by cultured human TEC cultures.

\section{Material and methods}

\subsection{Antibodies}

Anti-human cytokeratin mAb MNF 116 (lot 33) and rabbit polyclonal Abs anti-cytokeratin A575 (lot 31D) were obtained from Dako (Denmark). O33 and 013 are anti-OT mAbs; $\mathrm{O} 33$ is directed against the cyclic part of OT and $\mathrm{O} 13$ is directed against the C-terminal part of OT [25]. BER 312 is an anti-VP mAb [26]. Anti-IL-6 mAb (clone 4B2) was obtained from Medgenix Diagnostics (Belgium). Anti-LIF is a specific antiserum kindly provided by A. Godard [27]. Second antibodies were fluorescein (FITC)-conjugated Affinipure goat anti-mouse IgG (lot 28970), hereafter referred to as second antibody A; FITC-conjugated Affinipure goat anti-mouse IgM (lot 17708 ), hereafter referred yo as second antibody $\mathrm{B}$; and rhodamine (TRITC)-conjugated Affinipure $\mathrm{F}\left(\mathrm{ab}^{\prime}\right)_{2}$ fragment goat anti-rabbit IgG $(\mathrm{H}+\mathrm{L})$ (lot 27272), hereafter referred as second antibody $\mathrm{C}$. All conjugated Abs were obtained from Jackson (Pennsylvania).

\subsection{TEC cultures}

Thymus fragments were obtained from children (6 months to 3 years old) undergoing corrective cardiovascular surgery for congenital cardiopathies. Surgical fragments were pre-cut and washed by sedimentation at $1 \times g$, twice for $5 \mathrm{~min}$ in HBSS (Flow, 19-101-49), then minced with scissors and washed again. The small fragments $(<2 \mathrm{~mm})$ were then transferred in Eagle's minimum essential medium containing D-valine (Gibco) and supplemented with $2 \mathrm{mmol} / 1 \mathrm{~L}$-glutamine, $10 \mathrm{mmol} / 1$ HEPES, $100 \mathrm{U} / \mathrm{ml}$ penicillin, $100 \mu \mathrm{g} / \mathrm{ml}$ streptomycin and $10 \%$ heat-inactivated fetal calf serum (FCS; Gibco), hereafter referred as complete TEC medium. D-Valine was used to reduce the growth of fibroblasts $[28,29]$. Fragments were then allowed to attach to T-75 flasks in the same medium in a humidified atmosphere at $37^{\circ} \mathrm{C}$ and $5 \% \mathrm{CO}_{2}$, and complete TEC medium was replaced every 3-4 days. On day 17 , the explants and adherent cells were detached by treatment with Puck's-modified solution containing trypsin and EDTA (Gibco) and filtered through nylon gaze to eliminate fragment residues. Cells were counted and seeded at 6000 cells/well on 10 well/immunofluorescence microplates, and at 50000 cells/well in 12-well culture plates. The $10 \%$ FCS in complete medium was replaced at this point by $1 \%$ Ultroser G-steroid free (Gibco), hereafter designed as US-SF-TEC medium, for cytokine assays. Ultroser $\mathrm{G}$ was used in order to avoid possible artefacts reflecting the presence of cytokines in FCS, and to further reduce fibroblast growth [30].

\subsection{Immunofluorescence procedures}

Immunofluorescence microplates were kept for three days in FCS-TEC medium to allow plating of the TEC and then stained for immunofluorescence after a $7-\mathrm{min},-20^{\circ} \mathrm{C}$ methanol fixation [24]. Plates were first incubated for 30 min at room temperature with $10 \%$ normal goat serum to prevent non-specific binding of goat second antibody to mouse or rabbit immunoglobulins. Single or double immunostaining was performed with the following reagents: anti-human cytokeratins mAb MNF 116 diluted at 1:50 followed by second antibody $\mathrm{A}$; anti-OT $\mathrm{mAb}$ O33, diluted 1:100 followed by second antibody $B$; anti-IL-6 mAb diluted 1:10 followed by second $\mathrm{mAb}$ A diluted 1:40; anti-LIF antiserum diluted 1:50, followed by second antibody C. In some experiments MNF 116 was replaced by rabbit polyclonal anti-cytokeratin A575 diluted 1:200 followed by second antibody $\mathrm{C}$ diluted 1:100. Extinction controls were performed with second antibody alone, or after the first non-related antibody. In the double immunostaining studies, the first step was always performed with first mAb followed by the appropriate second antibody prior to immunostaining with polyclonal antiserum. After the final wash, the plates were mounted with glycerol/gelatin medium.

\subsection{Confocal microscopy}

Immunostained cells were imaged using a Bio-Rad MRC 100 laser scanning confocal unit mounted on an Axiovert 135 Zeiss inverted microscope. Images were collected with an $40 \times$ objective (aperture 1.3, plan Neofluar) or an oil immersion $63 \times$ objective (aperture 1.4, plan Apochromat). An Argon-Krypton ion laser source was utilized for fluorescein $(488 \mathrm{~nm})$ and for rhodamine $(568 \mathrm{~nm})$. Kalman filtering was used to integrate the signal collected over four frames to decrease the background noise. Photographs were taken using a camera mounted on a FVM 1702 Lucius and Bauer film recorder. 


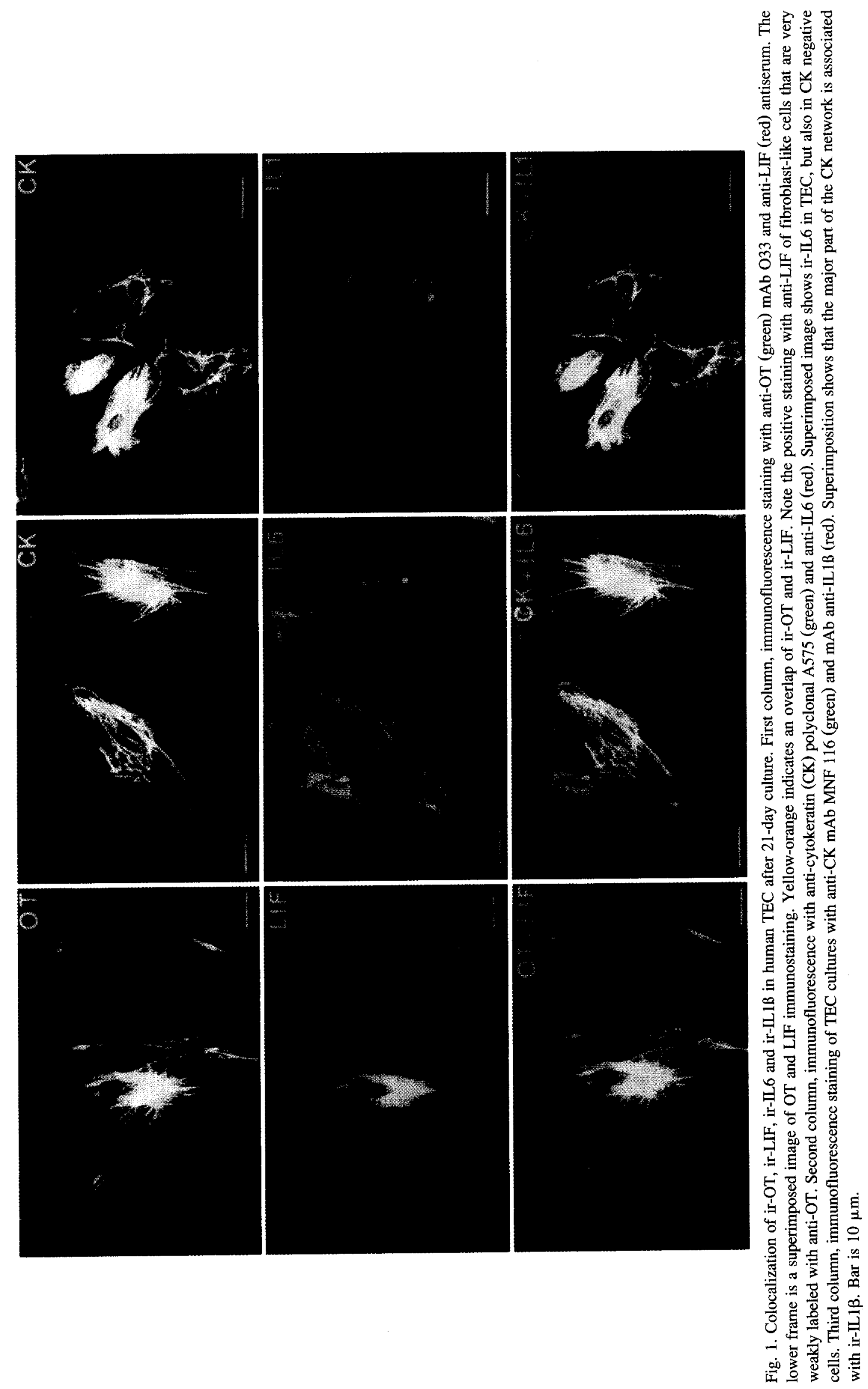




\subsection{Cytokine assays}

One $\mathrm{ml}$ of US-SF-TEC medium, with or without additives, was added on days 17, 21, 24 and 28 and supernatants collected for assay on days 21, 24, 28 and 31. Each experiment was repeated at least three times in duplicate. Collected medium was stored at $-20^{\circ} \mathrm{C}$ for cytokine measurements. Additives were anti-OT IgM O33 ascitic fluid, anti-OT IgG O13 ascitic fluid, anti-VP BER-312 ascitic fluid, mouse ascitic fluid depleted of IgG by three fast-flow protein-A affinity absorption, and $5 \mathrm{mg} / \mathrm{ml}$ mouse IgG (Sigma; lot 38F-8912), each at $1 \%(\mathrm{v} / \mathrm{v})$.

Cytokine levels were measured using $\mathbb{I L}-1 \beta$, IL- 6 and LIF EASIAs (Medgenix Diagnostics) according to published methods [31,32]

\subsection{Statistical analyses}

Values obtained from multiple experiments are reported as percentage $(\%)$ of basal value at each time point. Significance levels were determined by Mann-Whitney $U$-test.

\section{Results}

3.1. Cytokeratin (CK), ir-OT, ir-LIF, ir-IL-6, ir-IL-1 $\beta$ immunofluorescence in human TEC after 21-day culture (Fig. 1)

The staining obtained with anti-CK mAb demonstrates the dominant epithelial phenotype of cultured TEC. Counting of mAb-stained cells versus total cultured cells showed that $75-85 \%$ cells were authentic TEC (CK-positive) at day 21 , while $15-25 \%$ exhibited a fibroblast-like morphology. All cultured cells were stained with anti-LIF antiserum, with a slightly different pattern according to the cell of origin: bright filaments were stained in epithelial cell, while a speckled and diffuse staining pattern was observed in fibroblast-like cells (Fig. 1, first column). Ir-OT was found in very close association with the CK network. Epithelial cells appeared to be brightly stained with anti-IL-6, while anti- $\mathbb{L}-6$ staining was weaker in CK-negative cells (Fig. 1, second column). Ir-IL-1 $\beta$ was also detected in the cytoplasm of cultured human TEC associated with the major part of the CK network.

TEC and fibroblast-like cells were found to contain both ir-IL-6 and ir-LIF, while ir-OT was almost exclusively detected in epithelial (CK-positive) cells. Moreover, the combined use of confocal microscopy and immunofluorescence showed that anti-LIF and anti-OT outlined a common filament network in epithelial cells, while LIF immunoreactivity was much more less marked in fibroblast-like cells.
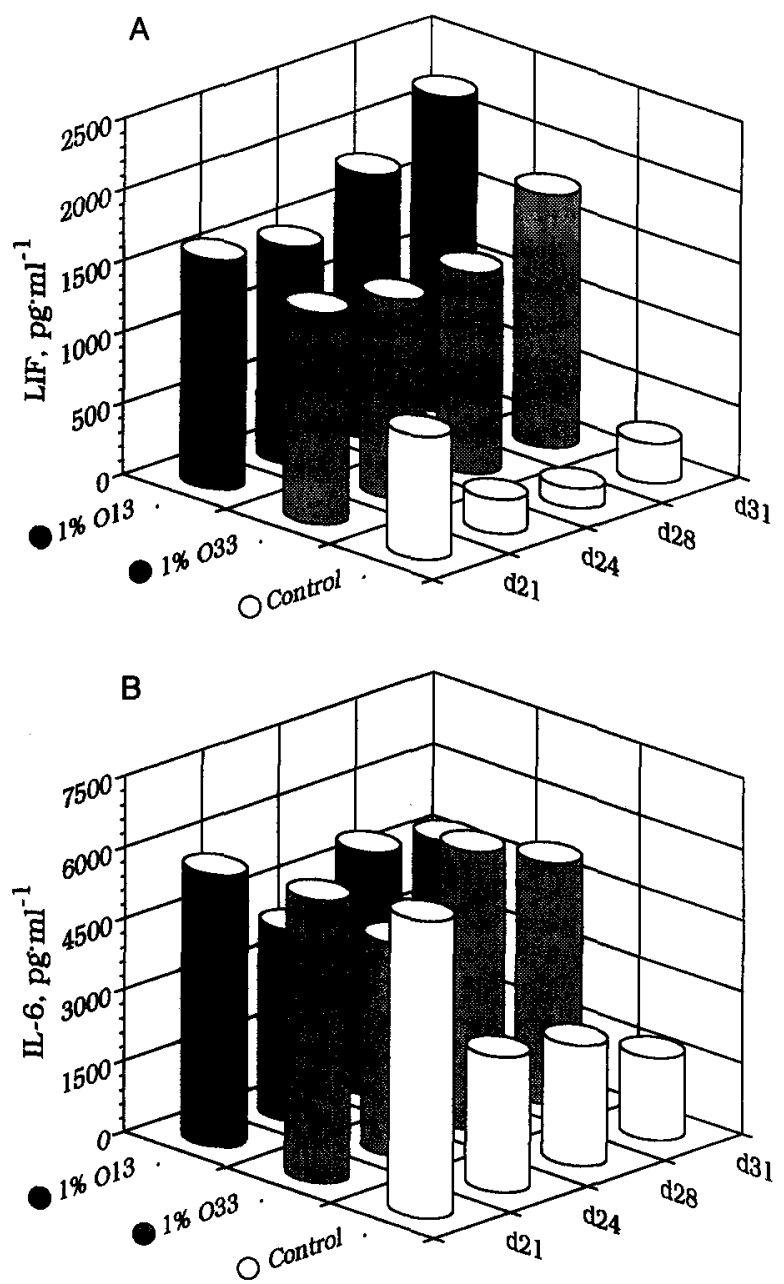

Fig. 2. Production of LIF and IL6 by human TEC: influence of $\mathrm{mAb}$ to OT O13 and O33. TEC supernatants tested for LIF (A) and IL6 (B) content at time indicated, from day 21 to day 31 . White columns are for control culture, grey are for $1 \% \mathrm{O} 33$ added-culture and black are for $1 \%$ O13. Each column is the mean of quadruplicate measurements, with c.v. less than $5 \%$

\subsection{Production of IL-6 and LIF by human TEC: Influence of mAbs to neurohypophysial peptides}

IL-1 $\beta$ was not detected in our experimental conditions, even in 5-fold concentrated medium, in either basal or mAb-stimulated TEC supernatants. As the detection limit of the IL- $1 \beta$ EASIA is $50 \mathrm{pg} / \mathrm{ml}, \mathrm{IL}-1 \beta$ production by 50000 cultured TEC is under $10 \mathrm{pg} / \mathrm{ml}$. On the other hand, under basal conditions cultured TEC produce 500 $1000 \mathrm{pg} / \mathrm{ml} \mathrm{ir-LIF}$, as well as $6-40 \mathrm{ng} / \mathrm{ml} \mathrm{ir-IL-6.} \mathrm{LIF}$ production showed a pronounced and sustained increase over basal when anti-OT O33 and O13 mAbs were added to TEC cultures (Fig. 2A). IL-6 production was sustained by the addition of anti-OT mAbs, in contrast with the rapid decrease under basal conditions (Fig. 2B).

\subsection{Controls}

LIF and IL- 6 production by human TEC were not affected by anti-VP mAb BER-312, by IgG-starved ascitic 

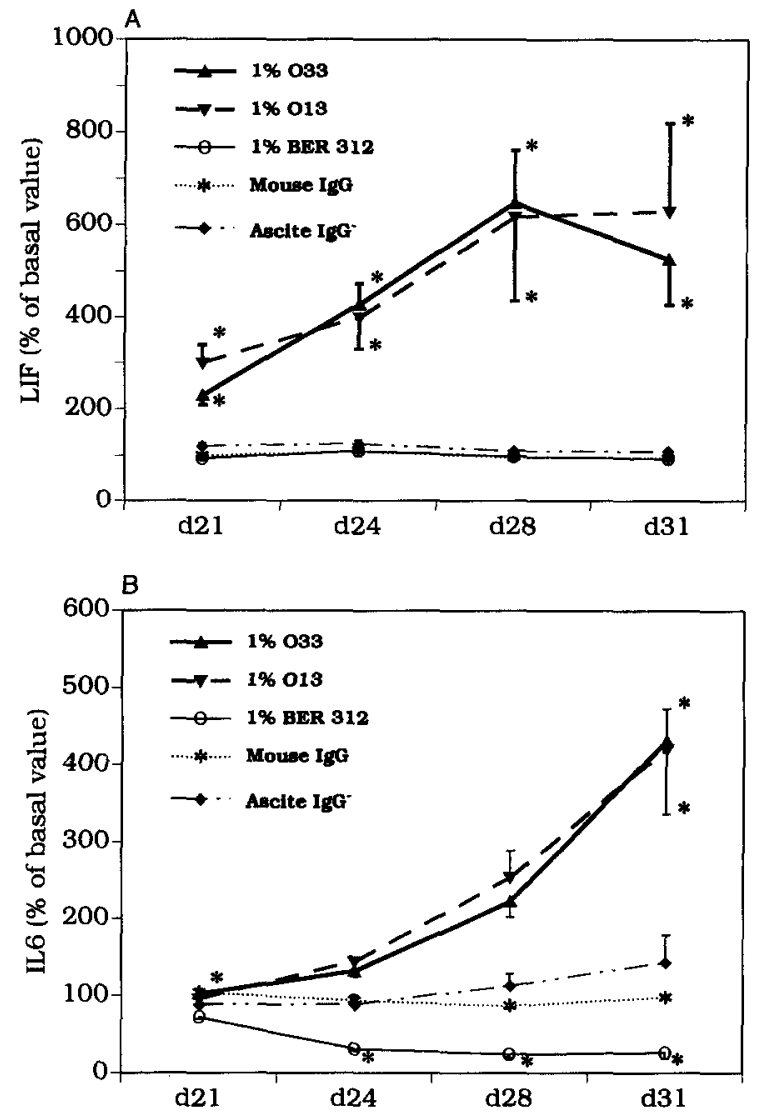

Fig. 3. Production of LIF and IL6 by human TEC: control experiments. Only mAbs to OT (O13 and O33) induced a marked increase of both LIF (A) and IL6 (B) production by human TEC. Anti-VP mAb BER-312, murine IgG, or murine ascitic fluid without IgG had no significant effect upon IL6. Anti-VP induced a significant inhibition of IL6 production. Each point is the mean of four experiments \pm SD in triplicate. ${ }^{*} P<0.001$, by Mann-Whitney $U$-test.

fluid, or by mouse IgG (Fig. 3A). In terms of IL-6 production, a slight but significant inhibitory effect of anti-VP BER-312 was observed (Fig. 3B). There was no significant difference between the positive effects of antiOT $\mathrm{O} 13$ and $\mathrm{O} 33$.

\section{Discussion}

The co-localization of ir-OT, IL-1 $\beta, \mathrm{IL}-6$ and LIF in cultured human TEC has been shown by combined immunofluorescence and confocal microscopy. OT and LIF staining in epithelial cells was closely related to the cytokeratin network on double immunofluorescence with anticytokeratin MNF $116 \mathrm{mAb}$. This finding suggests that the cytoskeleton of human TEC could be implicated in the processes of membrane translocation and secretion for this cell type. The results also are in close accord with previous ultrastructural analyses showing ir-OT to be diffusely located in the cytoplasm of murine TEC [12]. Cultured human TEC thus express both OT and cytokines, and the colocalization demonstrated confirms previous observations on human thymic sections [24]. Anti-OT staining of cultured TEC adds further evidence that OT is the dominant neurohypophysial-related peptide expressed in thymic epithelium.

A particular finding of the present study is that anti-OT mAbs strongly stimulate LIF and IL-6 secretion by cultured human TEC. The absence of EGF in US-SF might explain why ir-IL-6 is below detection limits under basal conditions, since biologically active and ir-IL-6 have been detected in human TEC culture in EGF-supplemented serum-free media, but not in DMEM or other EGF-deficient media [33]. Moreover, this cytokine has been shown to be regulated by EGF at a post-transcriptional level [34]. Colic et al reported IL-1 $\beta$ in the supernatants from rat TEC cultures [35], but Shoham et al found IL-1 $\beta$ below detection limits in murine and human TEC cultures [36,37]. Thus, species differences or culture methods could explain some of the discrepancies in the data previously reported.

The specificity of TEC activation by anti-OT mAbs has been carefully established by a variety of control experiments. It is not clearly due to a non-specific effect of Ig or ascitic fluid, nor did the anti-VP mAb exert any significant effect on LIF production, whereas it slightly inhibited ir-IL-6 production. As OT and VP differ by only two amino acids, the specific increase of cytokine production by TEC upon antigen recognition confirms that $O T$ is the dominant self-antigen of the neurohypophysial family expressed by TEC. Both $\mathrm{O} 33$ and $\mathrm{O} 13$ stimulate cytokine production by TEC, although $\mathrm{O} 13$ was previously shown not to stain human thymic sections [24,38]. In processing of the OT-precursor, OT must be cleaved from neurophysin before ${ }^{9}$ gly-OT amidation. The absence of TEC labelling by $\mathrm{O} 13$ may thus reflect incomplete processing of the OT precursor within the TEC cytoplasm. In contrast, the biological effects observed with 013 argue for presentation of fully-processed OT at the level of the TEC membranes.

The marked stimulating effect of anti-OT mAbs on TEC cytokine production may be explained by induction following immune recognition of the neurohypophysial-related antigen presented at the level of the TEC membrane. Altogether, these data strongly support a membrane localization of OT. The positive effects observed with two OT mAbs directed against different epitopes of the OT molecule strongly suggest that a fully processed OT is presented at the TEC plasma membrane. Somehow like the transduction following the binding of a signal to its receptor, the immunological recognition of OT leads to TEC activation reflected here by the secretion of IL- 6 and LIF. It will be also of interest to determine whether Abs against other thymic self-antigens such as neurokinin A [39] and insulin-like growth factor II $[40,41]$ are also able to affect TEC secretory activity. At the present stage, this study supports our model on the dual physiological role played 
in T-cell differentiation by the thymic repertoire of neuroendocrine-related polypeptides $[8,9]$.

\section{Acknowledgements}

V.G. is a Research Associate and Brigitte Malgrange is Senior Research Assistant of the National Fund of Scientific Research (Belgium). We thank Prof. J. Urbain (Laboratory of Physiology, Free University of Brussels, Rhode-Saint-Genèse, Belgium) who provided us with hybridomas producing anti-OT mAbs. These studies were supported by the Research Fund of Liège University Medical School, by the Fondation Léon Frédéricq of the Liège University Hospital, by the Fund for Scientific Medical Research of Belgium (grant No. 3.4562.90; grants Télévie No. 7.4611.91, 7.4548.93 and 7.4532.95), by the Association contre le Cancer (Belgium), and by the European Science Foundation (Strasbourg).

\section{References}

[1] Haynes, B.F., The human thymic microenvironment, Adv. Immunol., 36 (1984) 87-142.

[2] Sprent, J., Lo, D., Gao, E.-K. and Ron, Y., T cell selection in the thymus, Immunol. Rev., 101 (1988) 173-190.

[3] Muller, K.-P. and Kyewski, B.A., T cell receptor targeting to thymic cortical epithelial cells in vivo induces survival, activation and differentiation of immature thymocytes, Eur. J. Immunol., 23 (1993) $1661-1670$.

[4] Jenkinson, E.J., Anderson, G. and Owen, J.J.T., Studies on T cell maturation on defined thymic stromal cell populations in vitro, $\mathrm{J}$. Exp. Med., 176 (1992) 845-853.

[5] Hugo, P., Kappler, J.W. and Marrack, P.C., Positive selection of TcR alpha beta thymocytes: is cortical thymic epithelium an obligatory participant in the presentation of major histocompatibility complex protein?, Immunol. Rev., 135 (1993) 133-155.

[6] Bonomo, A. and Matzinger, P., Thymus epithelium induces tissuespecific tolerance, J. Exp. Med., 177 (1993) 1153-1164.

[7] Yukmanovic, S., Jameson, S.C. and Bevan, M.J., A thymic epithelial cell line induces both positive and negative selection in the thymus, Int. Immunol., 6 (1994) 239-246.

[8] Geenen, V., Martens, H., Robert, F., De Groote, D. and Franchimont, P., The thymic education of developing $T$ cells in self neuroendocrine principles, J. Endocrinol. Invest., 15 (1992) 621-629.

[9] Martens, H., Goxe, B. and Geenen, V., The thymic repertoire of neuroendocrine self-peptides: Physiological implications in T-cell life and death, Immunol. Today, 17 (1996) 312-317.

[10] Kelly, P.J., Blalock, J.E., Chrousos, G.P., Yu-Lee, L. and Geenen, V., Neuroendocrine hormones and the immune system. In A. Cuello and B. Collier (Eds.), Pharmacological Sciences: Perpectives for Research and Therapy in the Late 1990s., Birkhäuser, Basel, 1995, pp. 365-372.

[11] Geenen, V., Legros, J.J., Franchimont, P., Baudrihaye, M., Defresne, M.-P. and Boniver, J., The neuroendocrine thymus: Coexistence of oxytocin and neurophysin in the human thymus, Science, 232 (1986) 508-511.

[12] Wiemann, M. and Ehret, G., Subcellular localization of immunoreactive oxytocin within thymic epithelial cells of the male mouse, Cell Tissue Res., 273 (1993) 79-87.

[13] Elands, J., Resink, A. and de Kloet, E.R., Neurohypophysial hor- mone receptors in the rat thymus, spleen, and lymphocytes, Endocrinology, 126 (1989) 2703-2710.

[14] Martens, H., Robert, F., Legros, J.J., Geenen, V. and Franchimont, P., Expression of functional neurohypophysial peptide receptors by murine immature and cytotoxic T cell lines, Prog. NeuroEndocrinImmunol., 5 (1992) 31-39.

[15] Funder, J.W., Paracrine, cryptocrine, acrocrine, Mol. Cell. Endocrinol., 70 (1990) C21-C24.

[16] Geenen, V., Robert, F., Martens, H., Benhida, A., Degiovanni, G. Defresne, M.-P., Boniver, J., Legros, J.J., Martial, J. and Franchimont, P., Biosynthesis and paracrine/cryptocrine actions of "self" neurohypophysial-related peptides in the thymus, Mol. Cell. Endocrinol., 76 (1991) C27-C31.

[17] Geenen, V., Legros, J.-J., Franchimont, P., Defresne, M.-P. Boniver, J., Ivell, R. and Richter, D., The thymus as a neuroendocrine organ. synthesis of vasopressin and oxytocin in human thymic epithelium. Ann. NY Acad. Sci., 496 (1987) 56-66.

[18] Geenen, V., Vandersmissen, E., Martens, H., Goxe, B., Kecha, O., Legros, J.-J., Lefebvre, P.J., Benhida, A. Rentier-Delrue, F. and Martial, J.A., Cellular and molecular aspects of thymic T-cell education to neurohypophysial principles. In T. Saito, K. Kurokawa and S. Yoshida (Eds.), Neurohypophysis. Recent progress of vasopressin and oxytocin research. Proceedings of the First Joint World Congress of Neurohypophysis and Vasopressin, Excerpta Medica International Congress Series 1098, Elsevier, Amsterdam, 1995, pp. 309-319.

[19] Geenen, V., Vandersmissen, E., Cormann-Goffin, N., Martens, H., Legros, J.J., Degiovanni, G., Benhida, A., Martial, J. and Franchimont, P., Membrane translocation and relationship with MHC class I of a human thymic neurophysin-like protein, Thymus, 22 (1993) 55-66.

[20] Gainer, H. and Wray, S., Cellular and molecular biology of oxytocin and vasopressin. In E. Knobil and J.D. Neill (Eds.), The Physiology of Reproduction, 2nd Edn., Raven Press, New York, 1993, pp. $1099-1129$.

[21] Geenen, V. and Kroemer, G., The multiple ways to cellular immune tolerance, Immunol. Today, 14 (1993) 573-575.

[22] Le, P.T., Tuck, D.T., Dinarello, C.A., Haynes, B.F. and Singer, K.H., Human thymic epithelial cells produce interleukin-1, J. Immunol., 138 (1987) 2520-2526.

[23] Le, P.T., Lazorick, S., Whichard, L.P., Yang, Y.C., Clarck, S.C. Haynes, B.F. and Singer, K.H., Human thymic epithelial cells produce IL-6, granulocyte-monocyte-CSF, and leukemia inhibitory factor, J. Immunol., 145 (1990) 3310-3315.

[24] Robert, F., Geenen, V., Schoenen, J., Burgeon, E., De Groote, D. Defresne, M.-P., Legros, J.J. and Franchimont, P., Co-localization of immunoreactive oxytocin, vasopressin and interleukin- 1 in human thymic epithelial neuroendocrine cells, Brain Behav. Immun., 5 (1991) 102-115

[25] Burgeon, E., Chapleur, M., Schoenen, J., Remichius, D., Legros, J.J., Geenen, V. and Robert, F., Monoclonal antibodies to oxytocin: Production and characterization, J. Neuroimmunol., 31 (1991) 235244.

[26] Robert, F.R., Leon-Henri, B.P., Chapleur-Chateau, M.M., Girr, M.N. and Burlet, A.J., Comparison of three immunoassays in the screening and characterization of monoclonal antibodies against argininevasopressin, J. Neuroimmunol., 9 (1985) 205-220.

[27] Coupley, L., Berrada, L., Gascan, H., Godard, A. and Praloran, V., High titre antibodies obtained by intralymphnode immunization with low amounts of antigen, Cytokine, 5 (1993) 564-569.

[28] Gilbert, S.F. and Migeon, B.R., D-Valine as a selective agent for normal human and rodent epithelial cells in culture, Cell, 5 (1975) $11-17$.

[29] Small, M., Barr-Nea, L. and Aronson, M., Culture of thymic epithelial cells from mice and age-related studies on the growing cells, Eur. J. Immunol., 14 (1984) 936-942.

[30] Christensson, B., Biberfeld, P., Grafstrom, R. and Matell, G., In 
vitro culture of human thymic epithelial cells in serum-free media APMIS, 97 (1989) 926-934.

[31] De Groote, D., Zangerlé, P.F., Gevaert, Y., Fassotte, M.F., Beguin, Y., Noizat-Pirenne, F., Pirenne, J., Gathy, R., Lopez, M., Dehart, I., Igot, D., Baudrihaye, M., Delacroix, D. and Franchimont, P., Direct stimulation of cytokines (IL-1 $\beta$, TNF $\alpha$, IL-6, IL-2, IFN $\gamma$ and GM-CSF) in whole blood: I. Comparison with isolated PBMC stimulation, Cytokine, 4 (1992) 239-248.

[32] De Groote, D., Fauchet, F., Jadoul, M., Dehart, I., Gevaert, Y., Lopez, M., Gathy, R., Franssen, J.D., Radoux, D., Franchimont, P., Soulillou, J.P., Jacques, Y. and Godard, A., An Elisa for the measurements of human leukemia inhibitory factor in biological fluids and culture supernatants, J. Immunol. Methods, 167 (1994) 253-261.

[33] Andersen, A., Pedersen, H., Bendtzen, K. and Ropke, C., Effects of growth factors on cytokine production in serum-free cultures of human thymic epithelial cells, Scand. J. Immunol., 38 (1993) 233238.

[34] Le, P.T., Lazorick, S., Whichard, L.P., Haynes, B.F. and Singer, K.H., Regulation of cytokine production in the human thymus: epidermal growth factor and transforming growth factor- $\alpha$ regulate mRNA levels of interleukin- $1 \alpha$ (IL-1 $\alpha$ ), IL-1 $\beta$ and IL-6 in human thymic epithelial cells at a post-transcriptional level, J. Exp. Med., 174 (1991) 1147-1157.

[35] Colic, M., Pejnovic, N., Katanranovski, M., Stojanovic, N., Terzic, T. and Dujic, A., Rat thymic epithelial cells in culture constitutively secrete IL-1 and IL-6, Int. Immunol., 3 (1991) 1165-1174.
[36] Eshel, I., Savion, N. and Shoham, J., Analysis of thymic stromal cell subpopulations grown in vitro on extracellular matrix in defined medium. II. Cytokines activities in murine thymic epithelial and mesenchymal cell culture supernatants, J. Immunol,, 144 (1990) $1563-1570$.

[37] Meilin, A., Shoham, J. and Sharabi, Y., Analysis of thymic stromal cell subpopulations grown in vitro on extracellular matrix in defined medium. IV. Cytokines secreted by human thymic epithelial cells in culture and theiractivities on murine thymocytes and bone marrow cells, Immunology, 77 (1992) 208-213.

[38] Robert, F., Martens, H., Cormann, N., Benhida, A., Schoenen, J. and Geenen, V., The recognition of hypothalamo-neurohypophysial functions by developing T cells, Dev. Immunol., 2 (1992) 131-140.

[39] Ericsson, A., Genen V., Robert F., Legros, J.J., Vrindts-Gevaert, Y., Franchimont, P., Brene, S. and Persson, H., Expression of preprotachykinin $\mathrm{A}$ and neuropeptide $\mathrm{Y}$ mRNA in the thymus, Mol. Endocrinol., 4 (1990) 1211-1218.

[40] Geenen, V., Achour, I., Robert, F., Vandersmissen, E., Sodoyez, J.C., Defresne, M.-P., Boniver, J., Lefêbvre, P.J. and Franchimont, P., Evidence that insulin-like growth factor 2 (IGF2) is the dominant thymic peptide of the insulin superfamily, Thymus, 21 (1993) 115-127.

[41] Kooijman, R., van Buul-Offers, S.C., Scholtens, L.E., Schuurman, H.J., Van den Brande, L.J. and Zegers, B.J.M., T cell development in insulin-like growth factor-II transgenic mice, J. Immunol., 154 (1995) 5736-5745. 